Karolina Pszczoła

(Uniwersytet Jagielloński, Kraków - Polska)

\title{
LITERATURA WOBEC SZTUK PLASTYCZNYCH. WYBRANE PRZYKŁADY EKFRAZY W POEZJI UKRAIŃSKIEJ XX WIEKU
}

Relacje literatury i sztuk plastycznych od wieków budziły kontrowersje zarówno pośród twórców jak i teoretyków sztuki ${ }^{1}$ Dzisiaj to zagadnienie plasuje się $\mathrm{w}$ kręgu zainteresowań badawczo-interpretacyjnych komparatystyki intersemiotycznej². Szczególnym przypadkiem relacji literatury i sztuk plastycznych jest ekfraza - zjawisko o niedookreślonym statusie, funkcjonujące jako rodzaj retorycznej figury myśli, bądź też nabierające wymiaru gatunkowego (ekfraza poetycka). Dwudziestowieczna poezja ukraińska obfituje w różnego rodzaju ekfrastyczne przedstawienia, $w$ refleksji badawczej pojęcie to jest niemal nieobecne. Analiza dwóch zupełnie odmiennych sposobów realizacji ekfrazy - wierszy Mykoły Bażana i Ihora Kałyncia stanowi nową, dla tej poezji, propozycję interpretacyjną i włącza twórczość obu poetów w zakres badań intersemiotycznych.

Przed przejściem do analizy poszczególnych utworów należy zwrócić uwagę na wspomnianą powyżej niedookreśloność ekfrazy, problemy jej definicji i granic. Słownik terminów literackich pod redakcją Janusza Sła-

${ }^{1}$ O ich bliskości i podobieństwie pisał już w 23 r. p.n.e Horacy w Liście do Pizonów, udowadniając, że ut pictura poesis. Formuła ta na wieki zdeterminowała myślenie o „sztukach siostrzanych". Dopiero w XVIII wieku Gotthold Ephraim Lessing w Laookonie, czyli o granicach malarstwa i poezji sprzeciwił się takiemu pojmowaniu tych sztuk, jasno wyznaczając granice obu rodzajów twórczości artystycznej, podkreślając ich odrębność i specyfikę.

$2 \mathrm{O}$ granicach komparatystyki i jej wymiarze intersemiotycznym zob.: Badania porównawcze. Dyskusja o metodzie, red. A. Nowicka-Jeżowa, Izabelin 1998; B. Bakuła Historia $i$ komparatystyka. Szkice o literaturze i kulturze Europy Środkowo-Wschodniej w XX wieku, Poznań 2000; R. Etiemble, Porównanie to jeszcze nie dowód, „Pamiętnik Literacki” 1968, z. 3; Intersemiotyczność: literatura wobec innych sztuk (i odwrotnie), red. S. Balbus, A. Hejmej, J. Niedźwiedź, Kraków 2004; H. Janasek-Ivaničkowa, O wspótczesnej komparatystyce literackiej, Warszawa 1980; A. Kola, Nieklasyczna komparatystyka. W stronę nowego paradygmatu, „Teksty Drugie” 2008, z. 1-2; Komparatystyka dla humanistów, red. M. Dąbrowski, Warszawa 2011; Komparatystyka dzisiaj, problemy teoretyczne, red. E. Szczęsna i E. Kasperski, Kraków 2010, t. 1: Literatura a malarstwo - malarstwo a literatura. Panorama myśli polskiej XX wieku, red. G. Królikiewicz, O. Płaszczewska, I. Puchalska, M. Siwiec, Kraków 2009; S. Wysłouch, Literatura a sztuki wizualne, Warszawa 1994. 
wińskiego podaje bardzo skrótową i ograniczoną definicję terminu ekfraza tłumacząc ją jako „(gr. ekphrasis = dokładny opis) - utwór poetycki będący opisem dzieła malarskiego, rzeźby lub budowli, np. Oda do urny greckiej J. Keatsa" 3 . W polskiej refleksji badawczej ekfraza zagościła wraz $\mathrm{z}$ artykułem Edwarda Balcerzana ${ }^{4}$, który definiował ją jako pewien rodzaj transmutacji dzieła sztuki, formę krytyki artystycznej, rodzaj eseju lub recepcji obrazu ${ }^{5}$. Z biegiem czasu pojęcie to wzbogacało i uzupełniało swój zakres znaczeniowy. Istotny wpływ na kształtowanie się pojęcia miała działalność literaturoznawcza Andrzeja Nowakowskiego, który uznał, iż obraz stanowi jedynie punkt wyjścia dla poetyckich rozważań, używając przy tym interesujących sformułowań definiujących takich jak: "dokument przeżycia estetycznego" czy "horyzont obrazu"6. Elementy dominujące we współczesnym rozumieniu ekfrazy zaproponował Michał Paweł Markowski, wywodzący ekfrazę ze szkół rzymskiej retoryki i traktujący ją jako reprezentację. Markowski uwypuklił napięcie wyróżniające ekfrazę spośród innych form przedstawienia: $\mathrm{z}$ jednej strony zmierza ona do hypotypozy (unaocznienia przedmiotu), z drugiej na pierwszy plan wysuwa sposób prezentacji danego dzieła.

Nieco inne podejście do tej problematyki prezentuje Adam Dzia$\operatorname{dek}^{7}$, choć wyraźnie inspirowany myślą Markowskiego, rekomenduje stosowanie pojęcia „ekfrastyczności” w odniesieniu do tekstów współczesnych, jako że są one według niego niepełne - nie spełniają „wyznaczników ekfrazy". Sam wrocławski badacz wymienia jednakże wyłącznie dwa takie wyznaczniki. Pierwszym z nich są "wyraźne oznaki metajęzykowe, które bezpośrednio odsyłają do konkretnego dzieła sztuki malarskiej, rzeźbiarskiej lub architektonicznej"8 (tytuł, podtytuł, opatrzenie cyklu nazwiskiem malarza). Drugim wyznacznikiem są elementy opisu dzieła sztuki umieszczone wewnątrz tekstu literackiego, które pozwalają powiązać tekst z konkretnym dziełem. Korzystając z osiągnięć semiotyków (wstawienie dzieła sztuki jako interpretanta $\mathrm{w}$ triadycznym ujęciu znaku Charlesa Pierce'a, a także wykorzystanie terminu interpretanta wprowadzonego do literaturoznawstwa przez Michaela Riffaterra) w Obrazach i wierszach Dziadek oddziela od siebie dwa sposoby interpretacji związków literatury i sztuk plastycznych, ustalając ich

${ }^{3}$ Ekfraza, [w:] Stownik terminów literackich, red. J. Sławiński, Wrocław 2002.

${ }^{4}$ E. Balcerzan, Poezja jako semiotyka sztuki, [w:] Pogranicza i korespondencje sztuk, red. T. Cieślikowska, J. Sławiński, Wrocław 1980.

${ }^{5}$ A. Grodecka, Wiersze o obrazach, Poznań 2009, s. 15.

${ }^{6}$ A. Nowakowski, Poezja w galerii malarstwa. Rekonesans, „Rocznik Komisji Historyczno-Literackiej" 1990, nr 27, s. 177.

7 A. Dziadek, Obrazy i wiersze, Katowice 2011, s. 48-51.

8 Ibidem, s. 50. 
hierarchiczny porządek: obraz jako interpretant poezji oraz poezję jako interpretację sztuki.

Najpełniejszą jak dotąd definicję ekfrazy zaproponowała poznańska komparatystka - Aneta Grodecka. Stosując określenia zapożyczone z prac Mieczysława Wallisa i Mieczysława Porębskiego wyróżniła ona pięć typów. Pierwszy z nich, to ekfraza informacyjna, która ogranicza się do prezentacji obrazu poprzez narrację i opis. W tym przypadku fundamentalną była zasada wierności skrupulatnego wyjaśniania poszczególnych scen i rozwiązań malarskich, $\mathrm{z}$ czasem jednak obserwuje się odejście na tej zasady na rzecz swobody, a ekfrazy przeradzają się w wariacje uruchamiające różnorodne skojarzenia. Drugim typem jest ekfraza dyskursywna, przyjmująca formę wypowiedzi osób z obrazu (monolog lub dialog) i stanowiąca najczęściej rozszerzenie wszelakich gestów zamieszczonych przez malarza. Kolejna, to ekfraza inwokacyjna, czyli forma prośby lub modlitwy potencjalnego odbiorcy do namalowanej postaci. Najwcześniejsze realizacje tego typu ekfrazy dotyczą głównie obrazów religijnych. Ekfrazę syntetyczną najczęściej spotyka się w formie sentencji lub krótkiego komentarza, zwięźle ujętej zasadniczej myśli danego obrazu. Ostatnią odmianą jest ekfraza ekstatyczna, czyli próba zarejestrowania subiektywnych doświadczeń percepcyjnych, która koncentruje się wokół analizy warstwy malarskiej (koloru, przestrzeni, tworzywa) .

Problematykę ekfrazy zwykło się omawiać w kontekście relacji literatury i malarstwa, zupełnie na margines spychając kwestie relacji z architekturą. Pierwszy omówiony przeze mnie przykład ekfrazy w poezji ukraińskiej - wiersza Mykoły Bażana Katedra będzie dotyczył tego właśnie odniesienia. Jak stwierdza Alina Biała:

Sztuka literacka dysponuje środkami pozwalającymi imitować budowlę, tworzyć rozmaite jej obrazy oraz wywoływać wpływ na obserwatora. Dzięki temu dzieło architektury stanowi istotny motyw dla dzieł literackich. Jego nośnikiem są środki podawcze, głównie opis (rejestrujący wygląd obiektu) i opowiadanie (ukazując jego dzieje) ${ }^{10}$.

Warto w tym miejscu zaznaczyć, ze architektura wkroczyła do świata sztuki poprzez wykorzystanie elementów skoncentrowanych nie na funkcjonalności, ale na estetyce.

Kompozycja dzieła architektonicznego jest zawsze oparta na rygorach ścisłości myślenia geometrycznego i matematycznego, mających zapewnić budowli trwałość, a także piękno i harmonię formy. „Przymioty te często usiłowano przenieść na strukturę tekstu pisarza, przyrównując jego wysiłek twórczy do dzieła budowniczego"11. Szczegól-

\footnotetext{
9 Zob. A. Grodecka, op. cit., s. 28.

${ }^{10}$ A. Biała, Literatura i architektura. Korespondencja sztuk, Warszawa 2010. s. 21.

11 Ibidem, s. 22.
} 
nym przykładem „przekładu" dzieła literatury na architekturę stała się gotycka katedra, poprzez swoje odwołanie do środków ekspresji rzeźbiarskiej i malarskiej"12. Taka świątynia była Biblią dla ubogich „świętą księgą z kamienia”, którą czytał „nieczytający” człowiek wieków średnich. Katedra jest wzorcowym przykładem stylu gotyckiego, formą, w której styl ten realizuje się najpełniej, tu pośród najsłynniejszych na pierwszy plan wysuwa się francuska Notre Dame. Typowo gotyckie wieże, łuki, filary, elementy architektoniczne wysmuklające budowlę miały na celu wyrazić dążenia i myślenie ludzi wieków średnich - wzbić się ku niebu, przybliżyć do królestwa Bożego. Jak pisze Umberto Eco: „,...architektura jest sztuką, która najśmielej stara się odtworzyć swoim rytmem porządek wszechświata"13. Wszelakie ornamenty, czy to w postaci płaskorzeźby, czy malowideł wyrażały porządek wertykalny, jako odnoszący do transcendencji. Strzelistość, ciągłe wznoszenie się ku górze to najbardziej wyraziste cechy gotyku.

Przechodząc już do samego wiersza zacznę od jego pierwiastków konstrukcyjnych. Tutaj w pierwszej kolejności należy zwrócić uwagę na rytmikę utworów Bażana. Ukraiński poeta stosuje zwykle wiersz polimetryczny. W wierszu Katedra, jaki i w całym cyklu Budowle mamy różne jego warianty, lecz dominują dwu- i trójstopowe jamby. Rytmika ma za zadanie oddanie struktury gotyckiej budowli, która jest stosunkowo harmonijna, ale nie jest to harmonia oparta na prostej symetrii, lecz pełna niespodziewanych elementów, załamujących schematyczność szkieletu. Taki sam cel ma budowa eufonicznych i kakofonicznych zestawień dźwiękowych.

Warto w tym momencie spojrzeć na zjawisko syntezy sztuk w ogóle, również na innych płaszczyznach. Co ciekawe, Bażan usiłuje oddać fenomen architektury nie tylko za pomocą słownictwa specjalistycznego $\mathrm{z}$ tej dziedziny sztuki, ale również poprzez kontaminacje $\mathrm{z}$ wielkimi dziełami muzyki. Katedra staje się oratorium, kolumny dźwięczą niczym obój, kamienne mury odtwarzają ton „Dies irae”. Efekt przenikania się słowa i sztuki architektonicznej został osiągnięty poprzez oddanie osobliwości architektonicznych gotyk poprzez odpowiednio "ciężkie" metafory i epitety, antytezy i nietypowe zestawienia np. „pochmurna zawierucha lat"14, "strzeliste wieże - palców ostrych dotyk", "jaskinia wiary - rój odpustów".

Konsekwentne budowanie wiersza (rytm, metafora, obrazy) na zasadzie przeciwieństw odtwarza kontrastowość samej budowli, jest rów-

12 Por. ibidem, s. 21.

${ }^{13}$ U. Eco, Imię róży, tłum. A. Szymanowski, Warszawa 1987, s. 33.

14 Wszystkie cytaty poezji Bażana pochodzą z wydania: M. Bażan, Katedra, [w:] idem, Poezje wybrane, wybór i wstęp F. Nieuważnego, Warszawa 1986, s. 28-30. 
noznaczne z ideowo-kompozycyjną dwoistością wiersza. Utwór ten jest bowiem nie tyle opisem gotyckiej budowli, co stanowi pretekst do refleksji nad średniowiecznym sposobem myślenia, nad problematyką społeczną. Poeta obnaża paradoksy późnośredniowiecznego funkcjonowania. Z jednej strony, „kamienne Dies Irae” nawołuje do porzucenia grzesznego życia, nawrócenia, jest miejscem różańcowej modlitwy przypominającym o boskim gniewie i sądzie, „świątobliwy gotyk”. Z drugiej strony, jest to przede wszystkim miejsce wzniesione przez i dla feudałów, miejsce zbudowane na ludzkiej niedoli i cierpieniu. Poprzez zobrazowanie tej pamiątki architektonicznej poeta ukazuje rozłam myślenia późnego średniowiecza, którego wyrazem była właśnie sztuka gotycka. Katolicka katedra powstała na "sławę feudałów” i jest świadectwem wyzysku, impulsem do uświadomienia zwykłych ludzi. To potężne architektoniczne oratorium powstało wszakże z ludzkiej nędzy, "głodnych lat i ciał". W bezpośrednim zestawieniu obrazów artystycznych i społecznych ujawnia się wewnętrzny zamysł twórczy: finalna scena ukazuje wyszczerbione miecze i kosy Żakerii ${ }^{15}$ - synonim wystąpienia przeciwko szlacheckiemu porządkowi. Gotycka budowla jest zatem dla poety pretekstem umożliwiającym przejście do ogólnej refleksji nad dziejami, historią społeczną i kulturową.

Można by w tym miejscu zapytać dlaczego właśnie ta architektoniczna pamiątka prowadzi twórcę do takich rozważań? Za słowami Aliny Białej:

Dzieło architektoniczne, silniej niż inne rodzaje sztuki noszą $\mathrm{w}$ sobie znamiona historii, często to w budynkach najlepiej widać ślady historycznej zawieruchy, wiele mówią również o kulturowym charakterze danego regionu, tutaj zdecydowanie zaznacza się każda niejednorodnośćl6.

Gdybym miała opisać ten wiersz za pomocą kilku słów użyłabym metafory mówiącej, że podobnie jak katedra jest on tworem skonstruowanym, wyrzeźbionym z ciężkiego kamienia, który wywołuje wrażenie przepychu, majestatu i niepokoju. Nie na darmo ukraińskie literaturoznawstwo nazywa Bażana budowniczym/architektem słowa. Na zakończenie tej części pozwolę sobie jeszcze zacytować Jana Parandowskiego:

Konstrukcja, struktura, tymi słowami wyraża się najgłębsze pokrewieństwo: dzieło pisarza jak twór architektoniczny buduje się od podstaw, miesiącami, czy latami, powieść $\mathrm{w}$ swych rozdziałach rozkłada się jakby na piętra, a w wierszach nietrudno

15 Żakeria - powstanie ludowe w Francji w 1358 r., którego przyczyną było przede wszystkim wyzyskiwanie szerokich mas chłopskich przez grupy uprzywilejowane. Doszło do złupienia Paryża i zniszczenia wielu zamków. Bunt został krwawo stłumiony przez wojska króla Nawarry Karola II Złego, wojska francuskie i angielskie.

16 A. Biała, op. cit., s. 41. 
zobaczyć łuk, zwieńczenia, wiele elementów architektonicznych wiążących rozsypkę słów w twardą i mocną konstrukcję̨7.

Całkowicie inną realizacją w ekfrazy jest wiersz Ihora Kałyncia zatytułowany Na pocztówce - O. Bohomazow „Tracze”. Tryptyk18. Pierwsza z części tryptyku stanowi przede wszystkim dość dokładny opis obrazu z uwzględnieniem kolorystyki oraz techniki malarskiej:

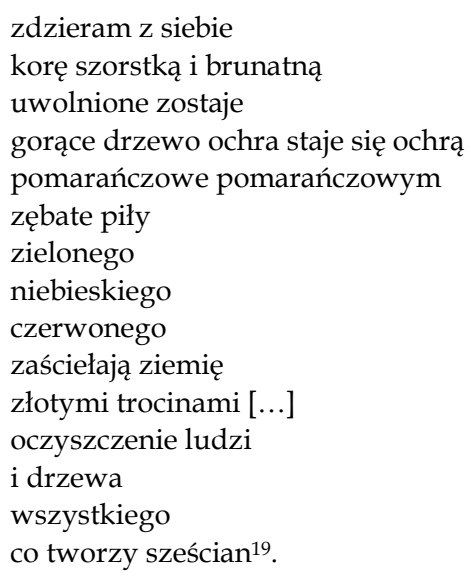

Choć podmiot liryczny konsekwentnie wyraża się w pierwszej osobie, to nie zawsze wypowiada się on "we własnym imieniu”. O ile w pierwszej części podmiot liryczny jeszcze może być postrzegany jako, mimo wszystko, zewnętrzny, choć niezwykle empatyczny obserwator, o tyle w drugiej części trudniej określić relację podmiot - bohater wiersza. Odnosi się wrażenie, iż osoba mówiąca $\mathrm{w}$ wierszu jest tożsama $\mathrm{z}$ bohaterem obrazu, wydaje się, że „przemawia głosem” drewnianych surowców, wyraża emocje i refleksje ontologiczne związane z bolesnym przeobrażeniem:

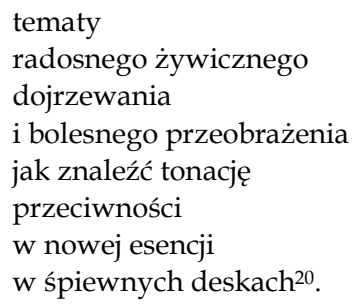

17 J. Parandowski, Refleksje, Wrocław 1975, s. 145.

18 I. Калинець, На листівиі - О. Богомазов „Пилярі". Триптих, [w:] того ж, Слово триваюче. Поезї, Харків 1997, s. 292-294.

${ }_{19}$ Ibidem, tłumaczenie własne.

${ }^{20}$ Ibidem, tłumaczenie własne. 
Również w kontekście wiersza Kałyncia należy wspomnieć szerzej o zjawisku interferencji sztuk w ogóle: i tutaj obraz i słowo przemawiają do odbiorcy za pomocą muzyczności, zarówno na poziomie fonetycznej gry, jak i na poziomie leksyki, mamy: tonację, śpiew, akordy.

W ostatnim fragmencie tryptyku podmiot ponownie staje raczej $\mathrm{w}$ pozycji obserwatora. Obraz Bohomazowa schodzi na dalszy plan, przywołane zostają natomiast inne wybitne postaci tak zwanego „rozstrzelanego odrodzenia"21 - Łeś Kurbas, słynny reżyser i twórca eksperymentalnego teatru ukraińskiego oraz Mykoła Kulisz, znakomity dramaturg, którego, moim zdaniem, uważać należy za prekursora teatru absurdu. "Ja" liryczne wyznaje jednak już na początku, że „zapomina" o nich (jak i o innych rzeczach czy zjawiskach, które zostają kolejno wymienione). Finał wiersza przynosi dość nieoczekiwaną scenę: tajemniczy „Białogłowy” dyryguje próbą/powtórką "piłowania lasu” i „niedoli wiórów”22. Dzieło ukraińskiego kubofuturysty staje się zatem obrazem poetyckim, swoistą metaforą losu wybitnych twórców ukraińskich. Sądzę, że można tutaj przyjąć dwie ścieżki interpretacyjne: odnieść sytuację "piłowania" do tych właśnie twórców i uznać je za synonim zniszczenia lub, co mnie samej wydaje się bliższym podejściem potraktować "wióry" jako społeczeństwo, które skrupulatnie „piłowane” przez system przeobraża się, przyjmuje nowe formy i zapomina, to, co $\mathrm{w}$ systemie totalitarnym zapomnieć należy. Jakimkolwiek tropem nie podążyć, nie można pominąć refleksji nad kondycją kultury ukraińskiej i jej odbioru.

Podsumowując, zakres problematyki omówionych przeze mnie utworów zawiera się w zagadnieniach związanych z komparatystyką intersemiotyczną. Uważam za właściwe przywołanie $\mathrm{w}$ tym kontekście pojęcia ekfrazy, jako że w obu tekstach wyróżnić można dwa podstawowe wyznaczniki ekfrazy, czyli metajęzykowe oznaki (odwołanie do konkretnego dzieła sztuki, często pojawiające się $\mathrm{w}$ tytule, podtytule, czy w inny sposób wyraźnie zasugerowane) oraz elementy opisu. O ile w przypadku wiersza Ihora Kałyncia, wymienione wyznaczniki są dość oczywiste, o tyle zasadność użycia pojęcia ekfrazy w stosunku do utworu Mykoły Bażana może podlegać dyskusji. Niemniej jednak, sądzę, że obydwa poetyckie przedstawienia mieszczą się $\mathrm{w}$ kategorii ekfrazy ekstatycznej opisanej przez Anetę Grodecką, przy czym wiersz Kałyncia zawiera pierwiastki właściwe innym jej typom (informacyjna, dyskursywna).

${ }^{21} \mathrm{Na}$ temat „rozstrzelanego odrodzenia” zob. m.in.: Ю. Лавріненко, Розстріляне відродження. Антологія 1917-1933, Київ 2004; O. Kocarev „Rozstrzelane odrodzenie” oraz strategie przetrwania, „Kultura Enter” 2008, nr 9, http://www.kulturaenter.pl/0/02dw4.html (03.02.2013); A. Korniejenko, Rozstrzelane odrodzenie, Kraków-Przemyśl 2010.

22 I. Калинець, оp. cit., tłumaczenie własne. 
Mimo zasadniczych i oczywistych różnic na płaszczyźnie poetyckiej obydwa utwory łączy jeszcze inna, niezwykle istotna cecha. Dla twórców dzieło sztuki jest impulsem do głębokiej refleksji dotyczącej kultury oraz społeczeństwa $\mathrm{w}$ konkretnym (dzięki referencyjności do dzieła sztuki właśnie) momencie dziejowym. Ponadto warto zaznaczyć, że przytaczane wiersze są częściami całych cykli poetyckich poświęconych dziełom malarskim i architektonicznym. Pojęcie ekfrazy w odniesieniu do całego kompleksu dzieł tych dwóch autorów otwiera możliwości nowych, pogłębionych interpretacji, czy reinterpretacji dotychczasowego sposobu postrzegania tej twórczości oraz wskazuje na intelektualne zakorzenienie obu poetów w kulturze. 